\title{
Pelatihan Membaca Simbol Phonetiks dengan Kamus Oxford Sebagai Upaya Peningkatan Akurasi Pengucapan dalam Bahasa Inggris
}

\author{
Dodi Siraj Muamar Zain ${ }^{1}$, Titi Wahyukti ${ }^{2}$ \\ dodisiraj@ump.ac.id ${ }^{1}$, titiwahyukti@ump.ac.id ${ }^{2}$ \\ Universitas Muhammadiyah Purwokerto
}

\begin{abstract}
Mistakes and errors in pronunciation will affect meaning distribution of certain words. In other words, one might have different interpretation for a certain message because of mispronunciation. In communication using English, pronunciation issues are mostly triggered by irregularity of letters' pronunciation in which the sounds might be different from the letters. It surely becomes a hindrance in classroom English learning. The use of Oxford dictionary employing phonetiks symbols can be an alternative to overcome mispronunciation problems. Different from common Indonesian-English dictionary, its contents are entirely presented in English. It offers certain challenges to students. Besides, students must also be able to read phonetiks symbols in order to pronounce words appropriately. This Community Service is aimed at introducing oxford dictionary as well as training students to read phonetiks symbols which are the reference in pronouncing English words correctly. During the workshop, students showed a great enthusiasm and all activities ran well. It is expected that form that point forward, students will be used to using Oxford dictionary and mispronunciation problems can be avoided.
\end{abstract}

Keywords: Phonetics symbols, Oxford Dictionary, Pronunciation

\begin{abstract}
Abstrak: Kesalahan dalam pengucapan kata akan berdampak tidak tersampaikannya makna dari suatu pesan. Dengan kata lain, seseorang mungkin akan memiliki interpretasi yang berbeda terhadap pesan yang disampaikan dikarenakan pengucapan kata yang tidak sesuai. Dalam komunikasi bahasa Inggris, permasalahan pengucapan yang sering muncul adalah adanya ketidakteraturan pengucapan huruf dimana apa yang diucapkan seringkali tidak sesuai dengan apa yang tertulis. Hal ini tentu saja menjadi kendala dalam pembelajaran bahasa Inggris di sekolah. Penggunaan kamus Oxford bisa menjadi salah satu pilihan untuk mengatasi permasalahan pengucapan kata dengan yang dialami siswa. Berbeda dengan kamus yang sering dipakai pleh siswa, kamus Oxford berisi konten yang seluruhnya dalam bahasa Inggris. Hal ini memberikan tantangan tersendiri kepada siswa. Selain itu, siswa juga harus mengenal simbol phonetik jika ingin mampu mengucapakan kata yang ada di dalamnya secara akurat. Kegiatan IbM ini ditujukan untuk memperkenalkan kamus Oxford serta melatih siswa untuk belajar membaca simbol phonetik yang merupakan acuan dalam pengucapan kata yang tepat dalam Bahasa Inggris. Selama kegiatan pelatihan, siswa menunjukkan antusiasme yang baik dan kegiatan pelatihan dapat berjalan dengan lancar. Diharapkan kedepannya siswa akan menjadi lebih terbiasa dalam menggunakan kamus oxford dan kesalahan pengucapan kata dapat dihindari.
\end{abstract}




\section{Dodi Siraj Muamar Zain ${ }^{1}$, Titi Wahyukti}

Kata Kunci: simbol phonetiks, kamus oxford, pengucapan

\section{ANALISIS SITUASI}

Kemampuan berbicara seringkali dijadikan tolak ukur kemampuan berbahasa seseorang. Hal ini berlaku Dalam komunikasi Bahasa asing khususnya Bahasa Inggris dimana seseorang akan dianggap mampu bilamana mampu menunjukan kemampuan berbicara yang memadai. Akan tetapi perlu dipahami bahwa kemampuan berbicara dalam Bahasa Inggris tidak hanya diukur dari kelancaran dalam penyampaian kalimat, tetapi ada aspek lain yang menjadi perhatian khususnya pengucapan kata. Akan memberikan sumbangsih yang cukup besar selama masa studi maupun dalam menghadapi dunia kerja (Kayi, 2012).

Pengucapan kata menjadi salah satu aspek penting dalam komunikasi lisan (Breitkreutz, et al. 2001). Untuk itu,perlu ditumbuhkan adanya rasa butuh untuk meningkatkan kemampuan pengucapan untuk memperoleh kemampuan berbahasa secara utuh (Hişmanoğlu, 2016). Pengucapan kata yang tidak sesuai memungkinkan tidak tersampaikannya ide atau pemikiran yang hendak disampaikan. Disamping itu, seringkali kemampuan dalam pengucapan yang kurang memadai menjadi kendala yang meyebabkan siswa enggan menggunakan Bahasa asing yag dipelajari (Baran-Łucarz, .2014)

Salah satu kendala yang dihadapi dalam pengucapan Bahasa Inggris oleh siswa adalah perbedaan system pengucapan yang ditemukan dalam Bahasa Inggris. Tidak seperti Bahasa Indonesia yang mengucapkan kata sesuai komposisi huruf di dalamnya, Bahasa Inggris memiliki model pengucapan yang tidak sistematis sebagaimana Bahasa Indonesia. Dengan kata lain, pengucapan kata tidak bisa didasarkan pada komposisi huruf yang terkandung dikarenakan adanya ketidak beraturan pengucapan huruf dari kata satu dengan kata yang lain.

Permasalahan mengenai pengucapan muncul dalam pembelajaran bahasa Inggris di SMA Muhammadiyah 1 Purwokerto. Pengucapan seringkali kurang mendapatkan perhatian dari guru. Sebagian besar guru masih menganggap bahwa fokus utama dari pembelajaran terletak pada susunan kata dan bentuk kata itu sendiri. Hal tersebut menunjukkan suatu indikasi bahwa dalam pembelajaran di kelas, guru lebih cenderung mengarahkan proses pembelajaran pada peningkatan kosakata siswa dan penyusunan kalimat yang tepat dengan mengesampingkan akurasi pengucapan kata. Siswa biasanya menerima input pengucapan kata dari hasil imitasi pada guru yang mengajar. Akan tetapi, seringkali guru tersebut memberikan contoh pengucapan yang kurang sesuai yang berakibat kesalahan pengucapan kata oleh siswa. Jika hal tersebut dibiarkan, akan muncul suatu gejala fosilialisasi/pengulangan kesalahan pengucapan secara terus menerus yang akan sangat menyulitkan untuk ditangani. 


\section{Dodi Siraj Muamar Zain ${ }^{1}$, Titi Wahyukti}

Siswa tidak memiliki acuan atau sumber belajar yang akurat dalam pengucapan kata berbahasa Inggris. Penggunaan kamus Oxford yang didalamnya terdapat simbol phonetics bisa menjadi solusi atas permasalahan tersebut. Namun, perlu diperhatikan bahwa penggunaan kamus Oxford tidak sama dengan kamus yang biasa dipakai siswa pada umumnya. Hal ini dikarenakan hampir semua siswa tidak pernah mempelajari huruf phonetiks yang merupakan kunci dalam membaca aturan pengucapan dari suatu kata dalam bahasa Inggris.

\section{SOLUSI DAN TARGET}

Pengucapan merupakan elemen penting dalam pembelajaran bahasa khususnya terkait dengan komunikasi lisan (Permana, 2018). Pengucapan yang tidak tepat akan menyebabkan tidak tersampaikannya pesan dalam suatu komunikasi. Akan tetapi, sayangnya pengucapan seringkali tidak mendapat perhatian khusus oleh sebagian guru di sekolah. Guru lebih cenderung memberikan prioritas lebih pada penambahan kosakata beserta makna yang terkandung di dalamnya. Disamping itu, masih banyak guru yang juga kurang mampu memberikan pengajaran pengucapan yang sesuai kepada siswa. kurangnya sumber belajar menjadi salah satu dasar permasalahan dari hal tersebut. Untuk mengatasi hal ini, penggunaan sumber ajar yang sesuai dengan kebutuhan guru dan siswa terkait pengucapan kata harus ditekankan dalam pembelajaran di kelas.

Pada kegiatan pengabdian ini, siswa akan diberikan pelatihan khusus dengan menggunakan sumber ajar yang mampu menjadi acuan dalam pengucapan kata-kata berbahasa Inggris. Sumber ajar ini berupa kamus Oxford yang merupakan salah satu acuan yang akurat dalam mengetahui pengucapan kata yang tepat dalam bahasa Inggris. Seperti telah dijelaskan sebelumnya, terdapat beberapa hal yang membedakan kamus Oxford dengan kamus yang biasa dipakai siswa di kelas. Terkait dengan model pengucapan kata, dalam kamus Oxford dikenal adanya simbol phonetik yang menjadi landasan dalam pengucapan kata. Simbol ini sendiri bagi sebagian besar siswa masih menjadi hal yang asing.

Melihat tantangan dalam penggunaan kamus Oxford ini, pelatihan ini akan mengarah pada pengenalan instruksi dalam kamus Oxford serta menekankan pada pengenalan simbol phonetik di dalamnya. Melalui kegiatan ini, diharapkan akurasi siswa dalam pengucapan akan meningkat dan siswa akan lebih terbantu dalam pembelajaran bahasa Inggris secara mandiri.

Tujuan secara umum dari kegiatan Ipteks bagi masyarakat ini adalah peningkatan akurasi siswa terkait pengucapan kata dalam bahasa Inggris melalui pelatihan membaca 


\section{Dodi Siraj Muamar Zain ${ }^{1}$, Titi Wahyukti}

simbol phonetiks dalam penggunaan kamus Oxford. Dalam hal ini, pelatihan yang akan dilakukan terkait dengan pengenalan huruf phonetik serta pengarahan dalam penggunaan dari kamus Oxford itu sendiri. Secara tidak langsung, hal ini akan mengurangi kemungkinan fosilialisasi kesalahan dalam pengucapan yang selama ini terjadi dalam proses pembelajaran.

Manfaat secara langsung adalah meningkatnya akurasi siswa dalam pengucapan kata dalam bahasa Inggris. Dengan pengucapan yang tepat, makna yang akan disampaikan siswa dalam kegiatan komunikasi khususnya komunikasi lisan akan tersampaikan dengan baik. Di samping itu, kegiatan ini juga memiliki manfaat tidak langsung yakni terdorongnya dan terbantunya siswa dalam kegiatan belajar bahasa Inggris secara mandiri. Dengan banyaknya input bahasa Inggris di luar kelas, proses pembelajaran bahasa Inggris yang secara tidak langsung terjadi pada diri siswa akan sedikit terbantu dengan tersedianya kamus Oxford sebagai acuan dalam pembelajaran. Dalam hal ini, kosakata yang dimiliki siswa juga akan bertambah .

\section{METODE PELAKSANAAN}

Khalayak sasaran dari kegiatan pengabdian ini adalah siswa SMA kelas X di SMA Muhammadiyah 1 Purwokerto. Lokasi pelaksaaan adalah di di SMA Muhammadiyah 1 Purwokerto, Jl. Dr. Angka, Purwokerto Selatan. Rangkaian kegiatan IbM ini sendiri dimulai dari persiapan yang dilakukan bulan Oktober dan dilaksanakan pada tanggal 29 Januari 2016 yang melibatkan 54 siswa di SMA Muhammadiyah 1 Purwokerto dari 2 kelas yang berbeda. Sebelumnya, kegiatan ini diawali dengan kegiatan koordinasi dengan kepala SMA Muhammadiyah Purwokerto untuk mengidentifikasi permasalahan yang muncul pada kegiatan belajar di kelas Bahasa Inggris. Dari kegiatan ini, diketahui bahwa salah satu permasalahan yang muncul adalah pengucapan dalam Bahasa Inggris. Setelah diadkan analisis permasalahan, tim pelaksana memformulasikan suatu gagasan untuk mengatasi masalah tersbut melalui pelatihan membaca symbol phonetiks dengan menggunakan kamus oxford. Tahap selanjutnya, tim kembali menghubungi pihak sekolah untuk melakukan pengajuan kegiata pengabdian dan setelah disetujui, kepala sekolah menetapkan jadwal pelaksanaan kegiatan dan salah satu wali kelas untuk menentukan peserta kegiatan.

Metode yang digunakan adalah melalui pelatihan kepada siswa dalam menggunakan kamus Oxford untuk mengarahkan siswa dalam pengucapan kata berbahasa Inggris secara tepat. Materi pelatihan diarahkan pada aturan penggunaan kamus Oxford dan cara membaca 
symbol phonetik. Dalan kegiatan ini, peserta akan melakukan proses pembelajaran dengan menerapkan tahapan pembelajaran yang telah dipaparkan sebelumnya.

a. Introduction (Pengenalan)

Tahap awal kegiatan ini adalah tahap pengenalan mengenai kamus oxford. Dari kegiatan ini, diketahui bahwa hamper keseluruan siswa belum mengenal kamus oxford. Oleh karena itu, penyaji memberikan pemaparan mengenai fungsi utama kamus oxford. Selain itu, kelebihan kamus oxford dibandingkan kamus yang lain juga disampaikan.

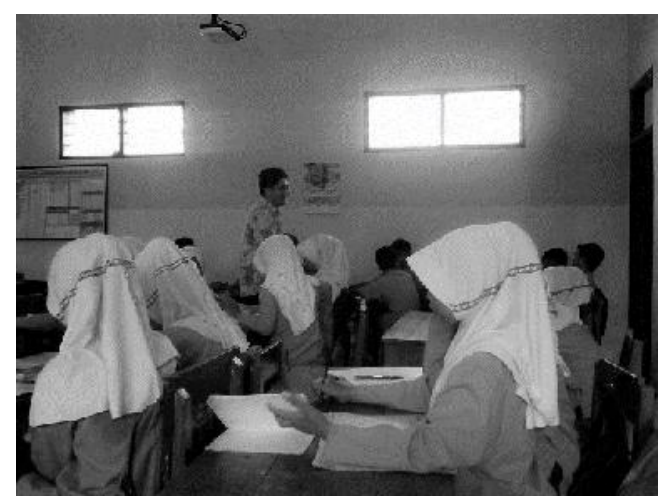

Gambar 1. Tahap pengenalan kamus oxford dan simbol phonetiks

Pada tahap ini, penyaji juga mengenalkan bagian-bagian dari kamus oxford baik berupa sinonim, jenis kata, maupun contoh penggunaan kata dalam kalimat beserta pengenalan mengenai simbol phonetiks sebagai acuan dalammembaca kata yang tepat dalam bahasa Inggris. Selama tahap pemaparan ini, masing-masing siswa dipinjami masing masing satu buah kamus oxford saku.

\section{b. Explanation (Penjelasan)}

Pada tahap ini, siswa dilatih membaca simbolphonetics dan melatih pengucapan kata dengan simbol tersebut. Beragam jenis simbol phonetik ditampilkan oleh penyaji. Dalam hal ini, penyaji memberikan pengarahan dengan meminta siswa memperhatikan contoh pengucapan huruf phonetiks. Siswa kemudian diminta untuk mengulangi apa yang diucapkan oleh penyaji.

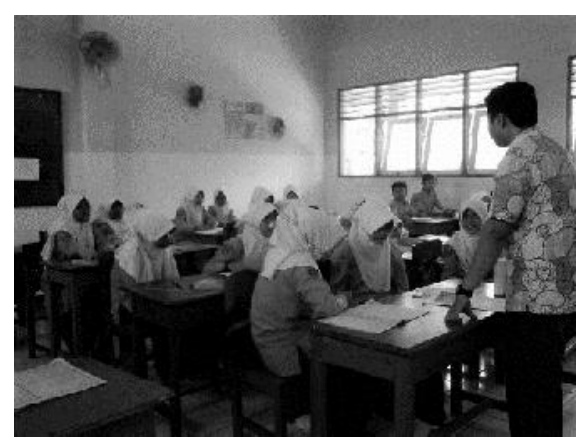

Gambar 2. Penyaji memberikan contoh pengucapan symbol phonetiks 


\section{Dodi Siraj Muamar Zain ${ }^{1}$, Titi Wahyukti}

Tim penyaji juga menggunakan media LCD untuk menampilkan simbol phonetiks dengan lebih jelas. Siswa kemudian diminta untuk mengucapkan simbol yang ditampilkan secara Bersama-sama.

c. Practicing (Latihan)

Pada tahap ini, siswa akan diberikan beberapa pelatihan dalam membaca simbol phonetiks. Siswa diberikan kertas latihan dimana mereka akan mengidentifkasi kata yang dimaksud dengan menampilkan simbol phonetiks yang merangkai kata tersebut.

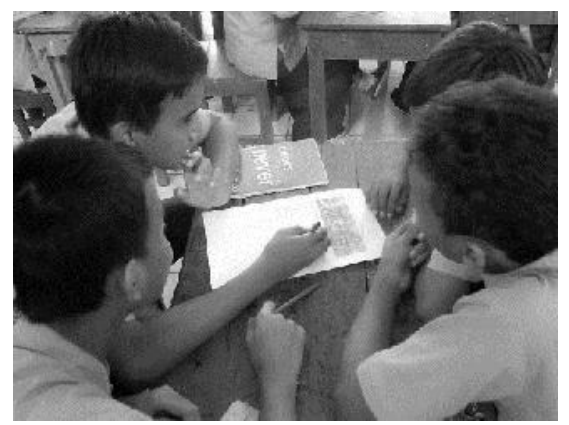

Gambar 3. Siswa secara berkelompok mengerjakan tugas yang diberikan.

Mengingat keterbatasan waktu, dalam menyelesaikan tugas yang diberikan, siswa mengerjakan soal tersebut secara berkelompok. Dalam kelompok tersebut, terdapat 4-5 orang siswa. Setelah menyelesaikan tugas tersebut, perwakilan siswa dari tiap kelompok diminta untuk menampilkan hasilnya di depan kelas.

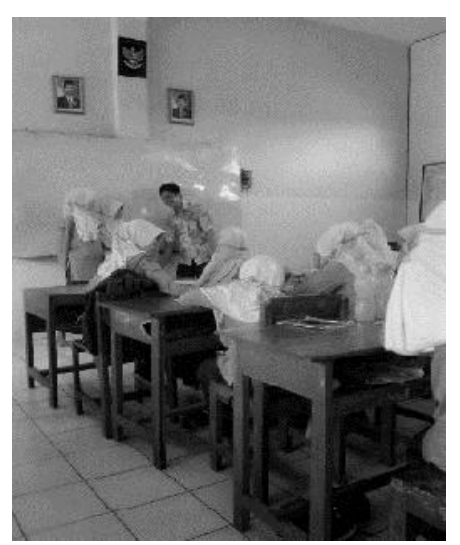

Gambar 3. Perwakilan siswa menampilkan hasil kerja.

\section{d. Conclusion}

Tahap akhir pada kegiatan ini adalah tahap menyimpulkan. Pada tahap ini, tim pelaksana dan siswa menarik kesimpulan mengenai apa yang telah dipelajari. Penyaji memberikan latihan singkat untuk melihat kemampuan individual melalui pemberian pertanyaankepada siswa. Dalam hal ini, tim penyaji menampilakn beberapa rangkain 


\section{Dodi Siraj Muamar Zain ${ }^{1}$, Titi Wahyukti ${ }^{2}$}

symbol phonetics dan meminta siswa untuk mengucapkannya. Sebagai penutup, penyaji meminta siswa untuk membaca simbol phonetikssekali lagi secara bersama-sama.

\section{HASIL DAN LUARAN}

Secara keseluruhan, kegiatan ini berjalan lancar mengingat tahap-tahapan kegiatan bisa dilaksanakan tanpa ada kendala. hal ini tentu saja memberi nilai positif pada diri siswa dimana mereka lebih termotivasi untuk berbicara dalam bahasa Inggris khususnya selama kegiatan belajar Bahasa Inggris. Hal ini terlihat dari antusiasme siswa untuk mengerjakan tugas yang diberikan serta menjawab pertanyaan yang diberikan selama kegiatan pelatihan ini berlangsung.

Secara lebih terperinci, luaran yang dihasilkan dari kegiatan pengabdian ini diantaranya adalah sebagai berikut.

1. Siswa memiliki pedoman dalam pengucapan kata yang tepat berbahasa Inggris.

2. Guru akan lebih mudah mengarahkan siswa dalam melakukan pengucapan yang tepat dan juga memperoleh masukan mengenai model pengucapan yang sesuai dengan kaidah yang tepat melalui pemahaman mengenai simbol phonetiks.

3. Siswa tidak segan lagi dalam menggunakan kamus Oxford di kelas dikarenakan telah memahami bagian-bagian penyusun di dalamnya.

Pelaksanaan pengabdian ini tidak terlepas dari dukungan universitas dalam menyediakan sumber-sumber bacaan baik dalam bentuk buku, modul, ataupun sumber dari internet. Oleh karena itu, tahapan pengabdian yang telah direncanakan dapat terlaksana dengan baik serta kelengkapan materi yang disampaikan dapat terpenuhi.

Kegiatan ini bukan tanpa hambatan. Hambatan yang muncul berasal dari siswa sebagai peserta kegiatan terkait waktu penyesuaian yang cukup lama bagi siswa untuk bisa menerima kegiatan pelatihan ini. Penyebabnya adalah peserta dan pelaksana kegiatan baru bertemu saat kegitan ini dilaksanakan. Namun, hal tersebut tidak menghalangi tercapainya tujuan dalam kegiatan ini.

\section{SIMPULAN}

Kegiatan ini diharapkan akan mampu meningkatkan motivasi berbicara siswa dalam Bahasa Inggris melalui kegiatan pembelajaran yang menarik berbasis pendekatan kontekstual. Hal ini tentu saja akan mengarah pada peningkatan kemampuan berbicara siswa. Dari kegiatan pengabdian ini, dapat disimpulkan bahwa kegiatan pelatihan peningkatan motivasi 


\section{Dodi Siraj Muamar Zain ${ }^{1}$, Titi Wahyukti}

siswa dalam berbicara pada mata pelajaran bahasa Inggris bagi siswa SMA Muhammadiyah IPurwokerto berlangsung dengan lancar sesuai yang telah direncanakan. Hal ini terlihat dari luaran yang dicapai dimana siswa-siswa telah mengetahui pemanfaatan dari pelatihan membaca symbol phonetikss dengan kamus Oxford dalampembelajaran Bahasa Inggris serta mereka mampu menggunakannya sebagai acuan pembelajaran khususnya dalam hal pengucapan kata.Dengan adanya pelatihan ini, siswa akan sangat terbantu dalam meningkatkan kosakata berbahasa Inggris. Disamping itu, siswa juga akan terhindar dari kesalahan pengucapan kata dikarenakan mereka telah memiliki acuan yang tepat.

Adapun hal yang menjadi pertimbangan untuk pelatihan kedepan antara lain:

1. Penggunaan waktu yang lebih optimal dengan menitikberatkan pada kegiatan diskusi. Pemateri diharapkan memberikan varian penugasan yang lebih beragam selama pelatihan.

2. dengan mempertimbangakan materi pelatihan yang masih dirasa asing bagi siswa, diperlukan pelatihan lanjutan yang diharapkan mampu membuat siswa terdirong dan terbiasa dalam menggunakan kamus Oxford.

3. Diharapkan diwaktu yang akan datang, kegiatan dengan tema yang sejenis bisa dilakukan di sekolah lain juga.

\section{DAFTAR RUJUKAN}

Baran-Łucarz, M. 2014. The link between pronunciation anxiety and willingness to communicate in the foreign-language classroom: The Polish EFL context. Canadian Modern Language Review, 70(4), 445-473.

Breitkreutz, J., Derwing, T., \& Rossiter, M. 2001. Pronunciation Teaching Practices in Canada. TESL Canada Journal, 19(1), 51-61. doi:https://doi.org/10.18806/tesl.v19i1.919

Hişmanoğlu, M. 2006. Current perspectives on pronunciation learning and teaching. Journal of language and linguistic studies, 2(1).

Kayi, H. 2012. Teaching speaking: Activities to promote speaking in a second language. Новейшие научные достижения, 12(2012).

Morley, J. 1991. The Pronunciation Component in Teaching English to Speakers of Other Languages. TESOL Quarterly, 25(3), 481-520. Jarolimek, John. \& Foster, Clifford D. 1976. Teaching and Learning in the Elementary School. USA: Macmillan Publishing Co. Inc.

Permana, E. P., \& Sari, Y. E. P. (2018). Development of Pop Up Book Media Material 
Dodi Siraj Muamar Zain ${ }^{1}$, Titi Wahyukti

Distinguishing Characteristics of Healthy and Unfit Environments Class III Students Elementary School. International Journal of Elementary Education, 2(1), 8-14.

Retrieved from https://ejournal.undiksha.ac.id/index.php/IJEE

Wong, R. 1987. Teaching Pronunciation: Focus on English Rhythm and Intonation. Englewood Cliffs, NJ: Prentice Hall Regents. 